\begin{tabular}{|l|l|l|l|l|}
\hline \multirow{2}{*}{ a plara } & ZYGO & zygo12103 & Dispatch: June 9, 2014 & CE: AFL \\
\cline { 2 - 6 } & Journal & MSP No. & No. of pages: 20 & PE: Angélique \\
\hline
\end{tabular}

\title{
AFFECTED BY NATURE: A HERMENEUTICAL TRANSFORMATION OF ENVIRONMENTAL ETHICS
}

\author{
by Francis Van den Noortgaete and Johan De Tavernier
}

\begin{abstract}
The value-action gap poses a considerable challenge to normative environmental ethics. Because of the wide array of empirical research results that have become available in the fields of environmental psychology, education, and anthropology, ethicists are at present able to take into account insights on what effectively motivates proenvironmental behavior. The emotional aspect apparently forms a key element within a transformational process that leads to an internalization of nature within one's identity structure. We compare these findings with studies on environmental activists, which appear to a significantly lesser degree hampered by the value-action gap, thereby attempting to understand what provides them with the drive to act more consistently on their moral attitudes. Hermeneutics is found to play a crucial role in the processes that lead to lasting and consistent motivation toward proenvironmental behavior. An empirically informed hermeneutical approach could therefore provide a promising impetus for contemporary environmental ethics.
\end{abstract}

Keywords: emotion; environmental ethics; mermeneutics; motivation; proenvironmental behavior; value-action gap

\section{StARING Down the GaP}

Ten years ago, Stewart Barr ironically posed the question whether we are all environmentalists now (Barr 2004, 231). Research indeed indicates thatin the general population - environmental awareness is high and that there is a widespread concern about the state of the environment. Nevertheless, we are faced with the widely observed phenomenon that this concern often does not translate into associated behavior (Hards 2012, 761). This apparent discrepancy is known as the "value-action gap" (Flynn et al. 2009), sometimes also referred to as the "attitude-action gap" (Mairesse et al. 2012), "theory-action gap" (Kretz 2012), "intention-behavior gap" (Davies et al. 2002), or "moral judgment-moral action gap" (Williams

Francis Van den Noortgaete is at Faculty of Theology and Religious Studies, Research Unit of Theological Ethics, University of Leuven, Sint-Michielsstraat 4, 3000 Leuven, Belgium; e-mail francis.vandennoortgaete@theo.kuleuven.be. Johan De Tavernier is at Faculty of Theology and Religious Studies, Research Unit of Theological Ethics, University of Leuven, Sint-Michielsstraat 4, 3000 Leuven, Belgium; e-mail johan.detavernier@theo.kuleuven.be. 


\section{Zygon}

and Gantt 2012). And if situational constraints may play a role in some instances (e.g., due to a lack of recycling provisions or facilities), these are clearly insufficient to account for it. In a recent extensive Canadian study, researchers found most respondents experiencing few if any situational barriers to proenvironmental behavior, yet 72 percent of them reported a gap between their intentions and their actions (Huddart et al. 2009, 157).

Even if some would consider technological development rather than human behavior as the main driver for proenvironmental change, it has been shown that increases in efficiency can be (and often are) countered by "rebound-effects," whereby the (cost-)efficiency of new technologies allows for increased consumption, undoing and sometimes even exceeding possible environmental gains (Sorrell and Herring 2009, 2). So, even from the viewpoint of techno-optimism, environmental change remains dependent upon the truly sustainable use of existing and new technologies (Midden et al. 2007, 159, 170; Steg and Vlek 2009, 309). The value-action gap's strong relevance appears to be quite independent of one's perspective on how to best tackle ecological challenges.

But what lies behind the discrepancy? Joe Heimlich and Nicole Ardoin argue that "research has consistently demonstrated that general proenvironmental attitudes alone rarely lead to specific behavioral changes" (2008, 222). Reviewing the body of available research in their 2009 monograph on conservation psychology led Susan Clayton and Gene Myers to conclude that "the link between attitudes or other cognitive constructs and behavior is typically weak or indirect" $(2009,33)$. Elizabeth Shove deconstructs any overly optimistic expectations by positing that the value-action gap "is only mystifying if we suppose that values do (or should) translate into action" $(2010,1276)$. Already in an early seminal article on the value-action gap, it was pointed out that many of the perspectives used in environmental education and policy are rooted in a rationalistic model. The key determinant of action is thereby assumed to be reasoned moral agency (Blake 1999, 264). These models of proenvironmental behavior are based on a linear progression: from environmental knowledge to environmental awareness and attitudes, which, in turn, are supposed to lead to proenvironmental behavior (Kollmuss and Agyeman 2002, 241). This view continues to be influential, even if research has shown that, in itself, it will not lead to the substantial behavioral changes hoped for (Owens and Driffill 2008, 4414). So-called "information-deficit" approaches, based on this widely criticized "knowledge-attitude-behavior" model of environmental learning (Goralnik and Nelson 2011, 183) and taking as a premise that providing further information influences attitudes on environmental issues, however, only have a limited impact on actual behavior and fail to durably engage people around the issues dealt with (McKenzie-Mohr 2000, 544; Agyeman and Angus 2003, 359). Based on his empirical research, ${ }^{1}$ Barr $(2004,246)$ argues that some people truly are environmentalists, but the rest know how 
to sound like one, capable of justifying conduct by means of a socially accepted environmental discourse, appropriated through education and the media.

Faced with certain trends in environmental change, different authors have therefore advocated a shift in focus, emphasizing the urgent need for ethics to address the value-action gap. Philosopher Lisa Kretz (2012, 9, 13) contends that environmental ethics should gain insight in how to facilitate morally justified behavior and recommends that the theory-action gap should be seen as a research priority. Educational expert Carol Booth argues along similar lines. To her, a "psychologically informed motivational framework for morality" is needed, since it will enable environmental ethicists to understand and address the challenges raised by the value-action gap (Booth 2009, 53, 56). Kretz concurs that environmental moral theory, practice, and pedagogy should be empirically rooted in moral psychology $(2012$, 9). There indeed is a real risk that, without sufficient attention to the value-action gap, ethics remains a discourse falling short of its normative aim. The available body of empirical research on proenvironmental behavior and the factors affecting it could provide valuable insights to increase the effectiveness of environmental ethics.

\section{A(N) (E)MOTIVE ForCE}

Over the past decade, rapid advances in the cognitive sciences have yielded empirical results that have challenged some of morality's core concepts. Research results from diverse subfields of psychology and neuroscience, including more recent brain-imaging research, provide indications that emotions play an influential role in moral deliberation (Craigie 2011, 54) and in moral education (McCuen and Shah 2007, 45). To philosopher Carla Bagnoli, the rise of the cognitive sciences is probably the most significant factor in the current philosophical reappraisal of emotions. She expects this to have an impact on the debate about the relation of emotions to morality (Bagnoli 2011, 12).

From combined neurophysiological measurements, including functional magnetic resonance imaging (fMRI), eye-tracking, and pupillary response studies of a large sample of individuals of different ages, Decety et al. conclude that emotion appears to play a crucial role in the development of morality $(2012,218)$. Psychologist Michelle Maiese is convinced that few theorists would still challenge the idea that emotion assists moral judgment, therefore being necessary for "a fully effective moral cognition" (Maiese 2013 , 1). Huebner et al., however, remark that the current neuroscientific research cannot really specify at what point(s) of the moral process emotions arise or intervene, even if there are persuasive indications that emotions do play a role in morality. They even contend that the current evidence remains insufficient to support the hypothesis that emotional processes 
would mediate moral judgment (Huebner et al. 2009, 1-2). However, they do admit that studies suggest that the most important and primary role emotions might have is precisely in motivating action.

When addressing the value-action gap, the emotional component therefore appears to be of key importance. Drawing on available studies of patients with either psychopathy, autism, or acquired sociopathy, Lisa Damm comes to the conclusion that due to their impaired affective capacities, they appear unable to display full moral agency. According to her, this suggests that "emotion is not necessary for possessing moral and social knowledge as embodied in rules and judgments. Nor does emotion appear to be necessary for exhibiting behavior that is consistent with moral norms. However, emotion does appear to be critical in bridging a gap in understanding in order to provide a motivational basis for why a person should show a distinctly moral concern for engaging in behaviors that exemplify moral norms" (Damm 2010, 288).

In this same light, it is interesting to see that in an experiment comparing "moral forecasting" and actual moral behavior, Teper et al. found that persons tend to inaccurately predict (mostly in the negative sense) how they will morally behave in certain situations. According to Teper et al., this is due to the respondents' inability, under experimental conditions, to access the affective component of actual experience in real-life moral dilemmas $(2011,557)$. Along similar lines, Feldman Hall et al. found that "enriching" the available contextual information leads to a better overlap between what one says and does. The more abstract reasoning and virtual ethical dilemmas will not accurately predict actual behavior. Real-life situations have a much more direct connection to the way one will effectively act, presumably so because the motivating emotional aspects are directly accessible (Feldman Hall et al. 2012, 440). This appears consonant to some more (neo-)Humean views in moral philosophy, emphasizing the "conative core of emotions." Such Humean approaches to morality, according to Bagnoli, also deny that reasoning directly motivates us $(2011,7)$.

\section{ENVIRONMENTAL SELVING}

Environmental psychology over the last decades has been extensively studying factors that influence human behavior toward the natural environment. At the turn of the millennium, a major international study on significant life experiences and formative influences affecting the proenvironmental behavior of adults, singled out childhood experiences of nature as the strongest determining factor (Palmer et al. 1998, 453; Palmer et al. 1999, 199). A positive connection to nature often takes root at an early stage of life and remains relatively stable afterwards (Müller et al. 2009, 60). Research indicates that time spent within "wild nature," in a participative way 
such as walking, playing, or camping during childhood, has a significant positive correlation with both adult environmental attitudes and behavior. Engaging as a child in more "domesticated" forms of nature such as planting, caring for and harvesting flowers or vegetables on the other hand is positively correlated to environmental attitudes, but only marginally to proenvironmental behavior (Wells and Lekies 2006, 13). There obviously is a clear difference between both types of activities. The experience of nature outside of the agricultural or gardening sphere permits what Bonnett calls an "apprehension of that quality of the self-arising in things," which is "beyond human authorship; present from out of themselves" (Bonnett 2012, 290). Apparently, it is the direct experience in and with nature as truly other, not as an object of control, which is significant in motivating care and concern for the natural world. One needs to acknowledge the "silent side" of such childhood experiences, which presume both a receptive and responsive sensitivity to nature (Chawla 1999, 380-81). Unfortunately, in some urban regions, opportunities for such experiences have become increasingly rare. This entails the risk of an "alienation" from nature and, as a consequence, more superficial contact that might not provide a similar experiential basis conducive to proenvironmental behavior (Bögeholz 2006, 65; Ritter and Dauksta 2013, 656). Based on an overview of the research on prosustainability learning, Paul Maiteny concludes that "the less experiential and more individualistic is the sense of connectedness to the environment, the more brittle the commitment to display appropriate behavior seems to be" (2002, 303-04).

Such participative child experiences of nature fall under the "experiential domain of knowledge," gained through the direct personal encounter with a subject, person, or a thing (e.g., a place). It entails knowledge through relationship and involves both cognitive and emotional connections (Burnard 1988, 128). According to Goralnik et al., it is the affective component, as suggested in the language of emotion and in the focus on relationships, which differentiates it from other forms of learning (2012, 417). One could speak of "emotionally engaged learning," considering emotion as an integral piece of the process (Chapman et al. 1995, 241). At a later stage of life, such learning is still conceivable but might become less evident, since through formal education and the influence of scientific and economic thought frames, nature will gradually become objectified and seen in utilitarian terms, which tends to weaken the emotional bond between humans and nonhuman nature (Kopnina 2012, 245-46). However, the encounter with nature only occurs authentically "through the immediate and sensuous engagement with the particularity and manifold suchness of emplaced things rather than through abstraction and intellectually constructed models" (Bonnett 2012, 292). Such an encounter requires a receptive disposition of heart and mind, the "adoption of an 
attitude that is neither an indifference nor a possessive desiring, but rather a dialogical openness" (Bonnett 2007, 716).

Such forms of experiential learning appear to be important for environmental ethics. It has been reported how the encounter with wild nature seems to revive a form of ethical intuition in students: "In the classroom, a student will often ask, in a tone that makes clear that the question is purely rhetorical, 'Who's to say what's right or wrong?' In the wild, by contrast, it begins to dawn on them that they know a great deal about right and wrong" (Frederickson and Johnson 2000, 180). Or, as Bonnett phrases it, "emplacement in an environment where nature is either immediately salient or is allowed to reveal itself involves a form of attunement that is normative in the sense of responding to what is already present and underway: a dimension of being that is potential yet to be fulfilled and that therefore requires a certain participative letting be on our part" (Bonnett 2012, 294). Experiential forms of learning contribute to the development of the necessary emotional maturity for ethical decision-making in context. By deepening the actual involvement with the ideas presented, the affective aspect motivates students to apply their environmental ethics knowledge (Goralnik et al. 2012, 416), confirming the findings of the more general research by Teper et al. and Feldman Hall et al., mentioned above.

Bonnett speaks of "knowledge by acquaintance," an acquaintanceship akin to the one between humans: "a direct, intimate, tacit knowledge that affects" (Bonnett 2007, 714). So, these experiential forms of learning can gradually evolve into a "connectedness" to nature, defined by Stephan Mayer and Cynthia McPherson Frantz as an "individual's affective, experiential connection to nature" (Mayer and McPherson Frantz 2004, 504). This has implications for one's proenvironmental stance: it has been found that individuals who associate themselves with the natural environment tend to hold broader sets of concerns for environmental issues. An individual with a less strong association between self and nature can still be sensitive to environmental issues, but these concerns are narrower, and focused on issues that directly affect him/her as an individual (Schultz et al. 2004, 40). An alternative way of approaching this has been through the concept of the "subjective level of commitment to the natural environment," defined as the psychological attachment to, and the long-term orientation toward, the natural world (Davis et al. 2009, 174). Commitment is thereby seen as the psychological experience of (inter)dependence, which in social psychology is precisely considered to be the descriptive, structural state of a relationship (Le and Agnew 2003,38). Davis et al. found that individuals who reported greater levels of commitment to the environment also reported greater proenvironmental behavior. This commitment-over time-can lead to a "transformation of motivation" so that, behaviorally, the well-being of the natural environment is taken into account, highly similar to what happens in interhuman personal relationships (Davis et al. 
$2009,175,178)$. So, a form of acquaintanceship develops "in which there is a knowing of the embodied by the embodied that, at its deepest level, apprehends the other in its alterity and not primarily as a vehicle or obstacle to satisfying our desires. Taken thus, it can be seen to constitute a kind of love" (Bonnett 2007, 716). Kevin Kim-Pong Tam recently compared seven different concepts and measures of "connection to nature" that have been devised and empirically tested within environmental psychology to be predictive of proenvironmental behavior $(2013,65) .{ }^{2}$ According to his findings, there is a strong convergence among these, indicating that they are based on a shared underlying phenomenon (Tam 2013, 74).

Wesley Schultz has linked connectedness to nature with the extent to which an individual includes nature within his/her cognitive representation of self/identity (Schultz 2002, 67-68). Utsler sees a hermeneutical dynamics at work in this construal of environmental identity, involving a process of repeated interpretation (Utsler 2014, 139-40). He particularly discerns a Ricoeurian dialectics in the development of an "environmental identity," a "self-understanding in relation to the environment" (Utsler 2009, 174). This inclusion of the other (in our case: nonhuman nature) as a part of the concept of self leads to a willingness to act on its behalf. This is a particular application of ideas from within the social psychology of interpersonal closeness: " $[t]$ he extent to which one includes another person as part of the self is a core operationalization of relationship closeness (...). Further, as relationship closeness increases, so does empathy and willingness to help" (Mayer and Frantz 2004, 504). And even if childhood experiences appear to provide a strong foundation for the inclusion of nature in one's concept of self, what is called "restoration" presents an interesting approach to such processes in adulthood. Natural environments have been shown to be restorative, causing a physiological and emotional winding down and/or the recovery of the capacity to focus attention. Such restoration is essential to a person's well-being, and natural environments were shown to have a marked restorative potential, in contrast to urban ones (Hartig et al. 2007, 291). According to Korpela, "places that a person can rely on for restorative experiences are thus more likely to be places for which attachments develop over time and that, in turn, come to figure in place identity" (Korpela et al. 2001, 573). Place identity, place attachment, and restorative experiences thereby appear to be "nested and reciprocally influential." So, these restorative experiences can be seen as an adult form of what we have called "emotionally engaged" encounters. It is moreover interesting to see that empirical research indicates that those who tend to resort to natural environments for these restorative capacities are also more inclined to proenvironmental behavior, a correlation that could resemble either a line or stairsteps, bringing a person "over successive motivational thresholds, each reflected in a distinct upward step in the intensity of ecological behavior performance" (Hartig et al. 2007, 297). 


\section{Zygon}

On a more general level, Collado et al. have found that even from an early age on, a feeling of connection with nature usually leads to more effortful behavior and an engagement with nature in later life $(2013,42)$. Encompassing nonhuman nature in one's sense of identity appears to provide a way of overcoming dualism or alienation (Tam 2013, 64). According to Susan Clayton, this encourages conservation behavior, because the object of protection is tied to the self. As a consequence, the motivation to act on nature's behalf becomes internal, rather than external. Considering nature as part of one's conception of identity, however, presumes a certain change in personal worldview, removing oneself as the sole center of things. Susan Clayton rightly points out that such a shift entails limits on human control of the natural environment: "we have to love what we get rather than create what we want" (Clayton 2003, 60). It seems that a relational paradox, a tension, applies here: encountering and treating nature as genuinely other, and as a consequence not under our control, is precisely the prerequisite for letting nature become part of the self. As Müller et al. found in a study of adolescents in Germany and Lithuania, the amount of time a young person spends in nature may contribute to positive feelings and an affinity toward nature. But it is only if nature has become a part of one's identity that it will actually be valued as something that has to be actively protected (Müller et al. 2009, 65). When moral attitudes are not duly internalized, coping strategies such as neutralization can develop to deal with the dissonance between values and actual behavior (Chatzidakis et al. 2007, 89-90). "Personal norms," however, defined as strongly internalized moral attitudes that have become part of one's self-concept, were shown to be directly predictive of the associated behavior (Davies et al. $2002,95)$. In a study on both the purchase of organic food and waste recycling, it was shown that "personal norms mediate not only the influence of subjective social norms, but in addition practically all behavioral effects of reported reasons and motives" (Thøgersen 2009, 358). Based on recent questionnaire-based empirical studies, van der Werff et al. also argue that "environmental self-identity" could be playing an important mediating role between values and behavior $(2013,62)$.

Lorraine Whitmarsh and Saffron O'Neill confirm the importance of identity in predicting proenvironmental behavior. However, from the lack of influence of environmental identity on-for instance-mobility or travel choices, even in those persons intent on proenvironmental behavior, they assume that individuals might actually be harboring several, and at times competing, identities. From their study, it appeared that the environmental identity conflicted with the social identities associated with car ownership or foreign holidays (Whitmarsh and O'Neill 2010,311-12). Susan Clayton and Amara Brook concur that it is the salience of the environmental identity that will determine to what extent it will lead to proenvironmental behavior $(2005,92)$. So, more than just an internalization of moral attitudes within 
one's environmental identity, integration of the different identities appears to be a crucial further condition. One could say that only if a person's multiplicity of identities is sufficiently harmonized, thereby retaining one's environmental identity as a significant part of a meaningful sense of self, then consistent and lasting proenvironmental behavior is to be expected. Bas Verplanken and Rob Holland phrase it thus: "once we perceive the situation as being relevant for a value that is central to our self-concept, we have the cognitive and motivational architecture to act on that value spontaneously" (Verplanken and Holland 2002, 445; emphasis added).

Even if emotion clearly plays an important role in the processes leading to the motivation of behavior, some of the emotional reactions experienced when exposed to environmental degradation can actually be distressing. Anja Kollmuss and Julian Agyeman have cautioned that these might lead to secondary psychological responses aimed at relieving us from these negative feelings, often of a sort that can stifle proenvironmental behavior. Psychologists distinguish between different defensive mechanisms such as denial, rational distancing, apathy, and delegation (Kollmuss and Agyeman $2002,255)$. Research indicates that the strength of one's connectedness to nature is an important factor in determining how these distressing emotions will impact on our behavior. According to different authors, people with a strong bond toward nature also do feel strong negative emotions concerning the state of the environment, but the positive feelings drawn from their relationship with nature apparently tend to outweigh these (Castn Broto et al. 2010, 955; Nisbet et al. 2011, 316).

\section{INSPIRING ANOMALIES}

The study of environmental activists, who seem to be hampered by the value-action gap to a significantly lesser degree and have actually dedicated (part of) their life to preserving or restoring the natural environment, also provides essential clues to understand this phenomenon. We agree with Carol Booth that we should learn from the motivations that do lead to genuine commitment $(2009,73)$.

According to their research on (professional) environmental activism, Jessica Kovan and John Dirkx found a "transformative learning process" at the core of these persons' sustained commitment $(2003,101)$. Transformative learning represents a fundamental change or shift in the understanding of oneself and of the relationship with the world in which one lives (Dirkx $2008,15)$. The concept has helped to elucidate the profound learning processes and the construal of meaning in case of paradigmatic shifts in human life, whether sudden or more gradual (Taylor 2007, 174). In what follows, we will be focusing on its phenomenological aspect, thereby making abstraction of any (post-) Jungian discourse sometimes used as an explanatory framework. 
Examining the biographies of figureheads of environmental engagement like Aldo Leopold, Rachel Carson, and David Suzuki, it was found by Pierre Walter that all of them had significant experiences bringing them to a lifelong commitment to nature preservation. For Leopold, this took the form of a close encounter with a dying wolf; for Carson and Suzuki, the processes were more incremental but also knew their distinctive, pivotal moment (a letter received, describing the effect of DDT on a bird sanctuary, and the confrontation with an area of clear-cut forest, respectively) that "tipped the balance" (Walter 2013, 29-36). These experiences were regarded by each of them as markedly emotional and appear to have provided a decisive motivational impetus, leading to their lifelong activism. Sarah Hards used a narrative approach to study transformation in people involved in proenvironmental practice and found that transformational moments are consistently described as strongly emotional experiences (2012, 769), a finding in line with those made by Kollmuss and Agyeman (2002, 254). In Kovan and Dirkx's aforementioned study, emotions are mentioned by interviewees as important and direct sources of knowledge, even though activists are reluctant to openly admit this for fear of ridicule or loss of professional sérieux $(2003,108,114)$. However, the motif of an "emotional calling" appears to be recurrent (Kovan and Dirkx 2003, 100; Walter 2013, 39). An empirical study by Lars Degenhardt, interviewing so-called "sustainable lifestyle pioneers," persons having adopted ecological patterns of behavior significantly beyond average, confirmed this crucial role of emotions. Analyzing their life histories using a biographical method, he found that "emotional consternation" formed an essential driving force for the implementation of a sustainable lifestyle. For these pioneers, emotionally powerful experiences in childhood and early teenage years that had triggered moral reflection often proved to be crucially important in their biography (Degenhardt 2002, 124, 142-43). This mirrors both Louise Chawla's and Schwantje Eigner and Peter Schmuck's conclusions that such childhood experiences are often highly important in providing the foundation for the activists' relationship with the environment, even if later formative circumstances can further strengthen this (Chawla 1999, 17). Eigner and Schmuck found that role models, formal education, parents, or other sources of encouragement potentially strengthen the motivation, but were not found to form part of the actual initiating core $(1998,42)$. The importance of sufficient freedom in childhood experiences, enabling what has been called an "emotional access" (emotionalen Zugang) to nature is underlined (Eigner and Schmuck 1998, 52). Chawla also found that this kind of informal outdoor activity is reported by environmental activists as the major determinant of their commitment (Chawla 1999, 25). So, the opportunity for emotionally engaging, unmediated experiences of nature, appears to be crucial. 
Sudden transformative moments or momentary shifts have been documented in the life stories of many environmentalist figures (Hards 2012, 763), but transformative learning usually does not occur in an "epiphanic" manner, rather through a more gradual "active engagement with everyday experience" (Kovan and Dirkx 2003, 107). Already Mezirow, founder of the concept of transformative learning, stated that it can occur either in the form of "accretion" or of a more "epochal" moment (Brock 2010, 136). Walter too sees the transformative learning of figureheads like Leopold, Carson, and Suzuki overall as gradual processes, integrating rational, emotional, and spiritual elements $(2013,38)$. This echoes Kovan and Dirkx's own observation that the environmental activists they interviewed also attribute their commitment to deep emotional and spiritual connections with nature, in addition to the obvious rational side of their professional activities $(2003,109)$. From a study of conservation volunteers, it was found that even if their commitment was less extensive than that of professional activists, they too phrased their connection to nature in cognitive, emotional, and even spiritual terms (Guiney and Oberhauser 2009, 192). The activists interviewed by Kovan and Dirkx mentioned a "multiplistic sense of self" in which each of these aspects has to be recognized in order to achieve a sense of wholeness. As a result of this, an integration of the self with the work is experienced, which feels like a natural extension of one's identity (Kovan and Dirkx 2003, 108-10). Illustrative of this integration, Eileen Crist studied the language used by naturalist writers to describe the life of animals. She found that their portrayal of animals "reveals that they understand animal life as subjectively meaningful" (Crist 1999, 86). This leads to a felt connection and a hermeneutical process relating outer and inner, which causes the naturalist to reassess the meaning of his/her own place. Thereby the lifeworld of the animal is "regarded as a spatial metaphor for the fullness of life (...) The lifeworld is not only the world of the stream of everyday actions, but one that is a world in common" (Crist 1999, 55, 57). The concept of an "expansive self," in which one's own identity includes the rest of nature, according to Bron Taylor already surfaces in the writings of Jean-Jacques Rousseau, and remains a key idea for a wide array of individuals and groups engaged in environmental action (Taylor 2010, 9).

Leslie Sponsel phrases the spiritual aspect within environmentalism as the conviction "that the ecocrisis will be resolved, or at least markedly reduced, only of there is a fundamental rethinking, refeeling, and revisioning of the place of humans in nature." Those involved "believe that religion and spirituality can generate such a profound transformation in many individuals, groups, and societies" (Sponsel 2011, 39; emphasis in original). From this viewpoint, the (immanently oriented) notions of spirituality within environmentalist thought appear to encapsulate the crucial emotional, relational, transformative, and hermeneutical aspects also found within the 
psychological research on proenvironmental behavior. So, this belief actually is a sound environmentalist intuition, whether or not it is framed in spiritual terms. Bron Taylor found such spirituality for instance to be operative in the surfing movement: "These experiences, and the cultural enclaves in which people reflect upon them, foster understandings of nature as powerful, transformative, healing, and sacred. Such perceptions, in turn, often lead to ethical action in which Mother Nature, and especially its manifestation as Mother Ocean, is considered sacred and worthy of reverent care" (Taylor 2010, 104).

The spiritual aspect should therefore not be interpreted in a classical religious sense. The activists interviewed repeatedly mentioned a sense of "not knowing." Somehow, a sense of calling, of vocation is strongly felt, but respondents are unaware of its origin (Kovan and Dirkx 2003, 106, 111). So, even if there is a form of spirituality operative, it appears to be of an agnostic kind. For some, what Bonnett has called the experience of the transcendent in the immanent leads to an ecstatic relationship with the natural world, which "can light up our consciousness by making a silent call upon us that takes us into an infinitely extending and mysterious universe where the known constantly rubs shoulders with the ineffable." (Bonnett 2012, 292). In a recent study on the link between the spiritual dimension of nature experience and environmental responsibility, it was found that those who experience nature in a spiritual way, "increasingly start to feel 'related' and 'connected' to their surroundings. Some participants explained sensing their physical boundaries as softening and becoming more porous to the environment. Others described it in terms of a sense of 'belonging' or 'homecoming'" (Hedlund-de Witt 2013, 171). Interestingly, those who stated that they "feel part of nature" were also "more inclined to identify with the interests or well-being of nature" (Hedlund-de Witt 2013, 172). Their connectedness to nature, spiritually articulated, fosters a drive toward proenvironmental behavior through forms of internalization. All of this has a marked hermeneutical dimension since, for most, such experiences are accompanied by a deep sense of purpose and meaning (Hedlund-de Witt 2013, 174).

Due to the emotional and spiritual aspects, however, at times these persons' vocational lifepaths run counter to purely rational considerations, entailing episodes of deep-felt struggle (Kovan and Dirkx 2003, 113). The transformative process can thereby lead to a felt tension between the internal and external (Kovan and Dirkx 2003, 108), since such learning processes not only transform one's individual perspective, but also have their impact on social relations (Lange 2004, 135). The aforementioned integration of different forms of identity, such as the environmental (or place) identity and the social identity, proves a gradual and at times difficult process. 
Summarizing, the same key elements motivating proenvironmental behavior, can be traced in the transformational life stories of environmental activists. These elements include the important role of the emotional and relational aspect, the integrative nature of the learning process and the integration of multiple identities (environmental, social) into a meaningful whole. Diduck et al. summarize that "it is widely believed that profound personal and social changes are required to break from unsustainable socialecological interactions, and that transformative learning theory is useful for explaining some of these change processes" $(2012,1312)$.

\section{AN EXPERIENTIAL-HERMENEUTICAL IMPETUS}

The ongoing empirical studies on proenvironmental behavior provide several insights relevant to environmental ethics. In the discussion above, we have gleaned some of the main lines surfacing in recent research. It has become clear that the whole of these processes proves to be deeply hermeneutical in character, showing a strong outer-inner dynamic of attributing meaning, whereby one's connection with nature changes the concept of self, in turn, affectively influencing our attitudes toward the natural world. When this dynamic is sustained, it can gradually and/or through sudden emotional moments lead to a strengthening commitment that can lastingly change behavior.

Our current environmental situation indicates that attempts at universal normative foundations for environmental ethics have proven to be insufficiently capable of dealing with a tenacious value-action gap. If environmental ethics aspires to be effective, it should let itself be inspired by what empirical research reveals to be conducive to enduring behavioral motivation. For it is precisely understanding "what determines reality from rhetoric," and trying to bridge them, that is essential (Barr 2004, 246-47). Acknowledging the important, affectively-driven hermeneutical processes which research reveals to be active in the transformative experience of nature, proves essential. To Bonnett, "ethical concern does not arise in some pure form of the kind that can adequately be articulated in sets of universal abstract principles. Rather it is the case that our antecedent involvement in a place (and therefore the world) conditions all understanding, including the ethical" (Bonnett 2012, 295).

Van Tongeren and Snellen recently asked the question "how hermeneutics might save the life of (environmental) ethics" $(2014,297)$, or at least provide a fresh impetus, different from the more classical approaches environmental ethics. For hermeneutics does not try to provide a rational foundation for norms, but, like environmental psychology, takes as its point of departure actual human (moral) experience (van Tongeren and Snellen 2014, 312). It takes into account the interplay of cognitive, emotional, and spiritual elements in the transformative experiential processes 
leading to motivated proenvironmental behavior. Hermeneutics simply begins by letting oneself be addressed. "Things have something to say to us, even if they do so in silence" (van Tongeren and Snellen 2014, 310). So, a crucial precondition is a receptivity to the alterity of nature, making such encounter possible. (Moral) experience needs interpretation insofar as there is something in the experience that calls for interpretation, withdrawing one from preconceived opinions, with which this other does not coincide. Meaning is thereby "received" (van Tongeren 1994b, 67). This is only possible when one lets something break through the usual or expected and does not remain indifferent to what it presents us with (van Tongeren 1994a, 203). For it is precisely that which does not fit our expectations, that challenges us to a hermeneutical dialogue (van Tongeren 1994a, 212). Such hermeneutics cannot manifest itself in a dichotomy between human subject and natural object (Utsler 2014, 139), but requires a noncontrolling, relational setting. In a stark contrast to this, a contemporary objectifying perspective of the world as resources "shapes the human understanding of reality in such a way, and at such a pervasive level, that we end up perceiving the totality of what is through resource-laden thought. This not only devastates the living world but also vastly diminishes humanity as well by boxing us into a virtually inescapable way of life through structuring our collective experience on Earth" (Crist 2012, 145). To Gadamer, such resource-laden thought even would preclude ethical thinking, since such a pragmatic-technical view entails a "detachment," both from nature and from oneself, that is foreign to ethical consideration (Smith 1988, 79).

This underlines the importance of repeated, participative, and emotionally engaging experiences of nature for motivation. These precisely provide opportunities to be "addressed" by nature in a way that invites us to interpretation, priming the hermeneutical dynamics that—eventually-leads to commitment and motivated proenvironmental behavior. It might not be easy for the remnants of nature we experience in (sub)urban areas to be sufficiently able to do so, since other, nonnatural elements in our surroundings drown out their call. Only when one becomes receptive to even tiny fragments of nature, like Albrecht Dürer in his famous watercolor Das große Rasenstück, can nature truly engage us.

Given the time needed for the hermeneutical processes to induce the necessary motivational transformation, van Tongeren and Snell make an appeal for a reappraisal of "patience" in order for a personal, integrated ethics to develop. This should allow for a growing self-understanding and the gradual discernment of the moral quality of one's life (van Tongeren and Snellen 2014,312 ). This involves an attitude of participation and a willingness to be affected, in contrast to the drive to order and to be "effective" (Bonnett 2007, 717). What these authors, writing from within the emerging field of environmental hermeneutics and hermeneutical ethics, suggest, might therefore differ considerably from the more problem-oriented approaches 
in normative ethics. In contrast to this, hermeneutics is "concerned with interpreting and clarifying the conditions and frameworks that determine those problems" (van Tongeren and Snellen 2014, 310). This presupposes an experiential "openness (that grows through life) to meaning" (van Tongeren 1994b, 67-68). The profoundly ethical dimension of this required hermeneutical openness was already clear to Hans-Georg Gadamer, for in his Truth and Method he wrote that it "involves recognizing that I myself must accept some things that are against me, even though no one else forces me to do so" (Gadamer [1960] 2013, 369). All of this obviously takes (hermeneutical) time in order to fully develop its motivating potential, and therefore resonates well with the transformative learning processes documented in those strongly committed to the conservation of the natural world.

From a hermeneutical perspective, Paul van Tongeren captured essential features now emerging from empirical research on what fosters proenvironmental behavior: "moral experience is being addressed by something or someone in such a way that, by inherent authority, we are summoned or obliged to commit ourselves to, or continue in, a certain way of acting or relating, or praxis, which is at the same time understood as being part of real or good human life" (van Tongeren 1994a, 204). Such a hermeneutical approach to ethics entails its own specific normativity, where nature calls us to moral response (van Tongeren 1994a, 205). Only in this dialogical manner will a proper recognition be possible of "nonhuman agency (whose intentional character, if any, we might suppose will be quite different to that of human agency) and the ways in which there is a reciprocal coresponsibility for the character of the places in which we live. Clearly, this represents a radical challenge to the traditional ethical position" (Bonnett $2012,297)$. Approaching the experience of nature from within a meaninggiving horizon also does not make the being of nature transparent nor does it deny "the inherent mystery in its self-arising. Quite the reverse. Mystery is only possible in the logical space where significances are in play" (Bonnett 2007, 715). Hermeneutical ethics is therefore also well-placed to accommodate the striking spiritual aspect emerging from anthropological research on environmental commitment.

But how to approach the challenge of hermeneutically rethinking environmental ethics? Already in 1994, van Tongeren stated that "ethics as hermeneutics" first "searches for constants and for possible ways to collect and arrange experiences, once they are put into words, under their common denominators, and by so doing, in a constantly ongoing process, to encompass the assembled experiences into a theory of moral life" and second "inquires about the structure of every possible moral experience, about the preconditions for the possibility of moral experience, or the moral character of our existence as understanding beings" (van Tongeren 1994a, 212). As he acknowledged, these two aspects are not to be seen 


\section{Zygon}

as consecutive steps, but will be mutually influential. What seems clear and what our article intends to establish, is that a dialogical openness to the contribution of other disciplines will thereby be essential. Developments within environmental psychology, education, and anthropology, even cognitive sciences, have over the past years been providing insights that are relevant for a nascent hermeneutical environmental ethics. Utsler therefore rightly advocates an interdisciplinary dialogue between environmental hermeneutics and environmental psychology (Utsler 2009, 140). We would suggest even a broader interdisciplinary scope, including environmental anthropology and education. The latter is even a key partner for environmental ethics, through its role of facilitating and studying experiential learning opportunities, fostering human recepticity toward nature and studying the aforementioned transformational processes, as specific forms of adult learning.

\section{CONCLUSION}

"We can be ethical only in relation to something we can see, feel, understand, love, or otherwise have faith in." (Leopold [1949] 1989, 214)

An environmental ethics that has the intention to impact the current state of the environment is in need of a thorough understanding of the value-action gap. This article has shown that this implies integrating research from other disciplines in order to comprehend what motivates proenvironmental behavior. What emerges from this process is the crucial importance of the emotional or affective component of our experience of nature. This appears to form the driving force of a hermeneutical, transformative process that gradually internalizes nature as a salient part of an integrated identity structure, which causes the gap between one's attitudes and behavior to gradually close.

More classical environmental-ethical approaches, rooted in cognitive and normative discourse, have proven to fall short of their aim by not acknowledging the importance of this transformation process and its inherent hermeneutics. Moreover, they struggle to come to terms with the spiritual aspects of natural experience articulated by those strongly relating to it. A hermeneutically oriented environmental ethics could provide fresh perspectives. Closely related to the broader emerging field of environmental hermeneutics, it presents us with an ethical challenge for the near future.

\section{NOTES}

1. Such as in his studies on the contrast between attitudes and actual behavior with regard to travel and mobility (Barr et al. 2011a; b).

2. Respectively "Commitment to Nature," "Connectedness to Nature," "Connectivity with Nature," "Emotional Affinity toward Nature," "Environmental Identity," "Inclusion of Nature in Self," and "Nature Relatedness" (Tam 2013, 65). 


\section{REFERENCES}

Agyeman, Julian, and Briony Angus. 2003. "The Role of Civic Environmentalism in the Pursuit of Sustainable Communities." Journal of Environmental Planning and Management 46:345-63.

Bagnoli, Carla. 2011. "Introduction." In Morality and the Emotions, ed. Carla Bagnoli, 1-36. Oxford: Oxford University Press.

Barr, Stewart. 2004. "Are We All Environmentalists Now? Rhetoric and Reality in Environmental Action." Geoforum 35:231-49.

Barr, Stewart, Gareth Shaw, and Tim Coles. 2011a. "Sustainable Lifestyles: Sites, Practices, and Policy." Environment and Planning A 43:3011-29.

Barr, Stewart, Gareth Shaw, and Andrew W. Gilg. 2011b. "The Policy and Practice of 'Sustainable Lifestyles'." Journal of Environmental Planning and Management 54:1331-50.

Blake, James. 1999. "Overcoming the 'Value-Action Gap' in Environmental Policy: Tensions between National Policy and Local Experience." Local Environment 4:257-78.

Bögeholz, Susanne. 2006. "Nature Experience and Its Importance for Environmental Knowledge, Values and Action: Recent German Empirical Contributions." Environmental Education Research 12:65-84.

Bonnett, Michael. 2007. "Environmental Education and the Issue of Nature." Journal of Curriculum Studies 39: 707-21.

. 2012. "Environmental Concern, Moral Education and our Place in Nature." Journal of Moral Education 41:285-300.

Booth, Carol. 2009. "A Motivational Turn for Environmental Ethics." Ethics and the Environment 14:53-78.

Brock, Sabra E. 2010. "Measuring the Importance of Precursor Steps to Transformative Learning" Adult Education Quarterly 60:122-42.

Burnard, Philip. 1988. "Experiential Learning: Some Theoretical Considerations." International Journal of Lifelong Education 7:127-33.

Castn Broto, Vanesa, Kate Burningham, Claudia Carter, and Lucia Elghali. 2010. "Stigma and Attachment: Performance of Identity in an Environmentally Degraded Place.” Society \& Natural Resources 23:952-68.

Chapman, Steve, Pam McPhee, and Bill Prodman. 1995. "What is Experiential Education?” In The Theory of Experiential Education, eds. Karen Warren, Mitchell Sakofs, and Jasper S. Hunt, Jr., 235-47. Boulder, CO: Association for Experiential Education.

Chatzidakis, Andreas, Sally Hibbert, and Andrew P. Smith. 2007. "Why People Don't Take Their Concerns about Fair Trade to the Supermarket: The Role of Neutralisation." Journal of Business Ethics 74:89-100.

Chawla, Louise. 1999. "Life Paths into Effective Environmental Action." The Journal of Environmental Education 31:15-26.

Clayton, Susan. 2003. "Environmental Identity: A Conceptual and an Operational Definition." In Identity and the Natural Environment, eds. Susan Clayton and Susan Opotow, 45-65. Cambridge, MA: MIT Press.

Clayton, Susan, and Amara Brook. 2005. "Can Psychology Help Save the World? A Model for Conservation Psychology.” Analyses of Social Issues and Public Policy 5:87-102.

Clayton, Susan, and Gene Myers. 2009. Conservation Psychology. Understanding and Promoting Human Care for Nature. Oxford: Wiley-Blackwell.

Collado, Silvia, Henk Staats, and José A. Corraliza. 2013. "Experiencing Nature in Children's Summer Camps: Affective, Cognitive and Behavioral Consequences." Journal of Environmental Psychology 33:37-44.

Craigie, Jillian. 2011. "Thinking and Feeling: Moral Deliberation in a Dual-Process Framework." Philosophical Psychology 24:53-71.

Crist, Eileen. 1999. Images of Animals. Anthropomorphism and the Animal Mind. Philadelphia, PA: Temple University Press.

— 2012. "Abundant Earth and the Population Question." In Life on the Brink. Environmentalists Confront Overpopulation, eds. Philip Cafaro and Eileen Crist, 141-53. Athens: University of Georgia Press.

Damm, Lisa. 2010. "Emotions and Moral Agency." Philosophical Explorations 13:275-92. 


\section{Zygon}

Davies, Janette, Gordon R. Foxall, and John Pallister. 2002. "Beyond the Intention-Behavior Mythology: An Integrated Model of Recycling." Marketing Theory 2:29-113.

Davis, Jody L., Jeffrey D. Green, and Allison Reed. 2009. "Interdependence with the Environment: Commitment, Interconnectedness, and Environmental Behavior.” Journal of Environmental Psychology 29:173-80.

Decety, Jean, Kalina J. Michalska, and Katherine D. Kinzler. 2012. "The Contribution of Emotion and Cognition to Moral Sensitivity: A Neurodevelopmental Study." Cerebral Cortex 22:209-20.

Degenhardt, Lars. 2002. "Why Do People Act in Sustainable Ways? Results of an Empirical Survey of Lifestyle Pioneers." In Psychology of Sustainable Development, eds. by Peter Schmuck and Wesley P. Schultz, 123-47. Dordrecht: Kluwer.

Diduck, Alan A., John Sinclair, Glen Hostetler, and Patricia Fitzpatrick. 2012. "Transformative Learning Theory, Public Involvement, and Natural Resource and Environmental Management." Journal of Environmental Planning and Management 55:1311-30.

Dirkx, John M. 2008. "The Meaning and Role of Emotions in Adult Learning." New Directions for Adult and Continuing Education 120:7-18.

Eigner, Swantje, and Peter Schmuck. 1998. "Biographische Interviews mit Umwelt- und Naturschützern." Umweltpsychologie 2:42-53.

Feldman Hall, Oriel, Dean Mobbs, Davy Evans, Lucy Hiscox, Lauren Navrady, and Tim Dalgleish. 2012. "What We Say and What We Do: The Relationship between Real and Hypothetical Moral Choices." Cognition 123:434-41.

Flynn, Rob, Paul Bellaby, and Miriam Ricci. 2009. "The 'Value-Action Gap' in Public Attitudes towards Sustainable Energy: The Case of Hydrogen Energy." The Sociological Review 57:159-80.

Fredrickson, Laura M., and Baylor L. Johnson. 2000. "Wilderness: A Place for Ethical Inquiry." USDA Forest Service Proceedings 3:177-80.

Gadamer, Hans-Georg. (1960) 2013. Truth and Method. London: Bloomsbury Academic.

Goralnik, Lissy, and Michael P. Nelson. 2011. "Framing a Philosophy of Environmental Action: Aldo Leopold, John Muir, and the Importance of Community." The Journal of Environmental Education 42:181-92.

Goralnik, Lissy, Kelly F. Millenbah, Michael P. Nelson, and Laurie Thorp. 2012. "An Environmental Pedagogy of Care: Emotion, Relationships, and Experience in Higher Education Ethics Learning." Journal of Experiential Education 35:412-28.

Hards, Sarah. 2012. "Tales of Transformation: The Potential of a Narrative Approach to ProEnvironmental Practices." Geoforum 43:760-71.

Hartig, Terry, Florian G. Kaiser, and Einar Strumse. 2007. "Psychological Restoration in Nature as a Source of Motivation for Ecological Behaviour." Environmental Conservation 34:29199.

Hedlund-de Witt, Annick. 2013. "Pathways to Environmental Responsibility: A Qualitative Exploration of the Spiritual Dimension of Nature Experience." Journal for the Study of Religion Nature and Culture 7:154-86.

Heimlich, Joe E., and Nicole M. Ardoin. 2008. "Understanding Behavior to Understand Behavior Change: A Literature Review.” Environmental Education Research 14:215-37.

Huddart Kennedy, Emily, Thomas M. Beckley, Bonita L. McFarlane, and Solange Nadeau. 2009. "Why We Don't 'Walk the Talk': Understanding the Environmental Values/Behavior Gap in Canada." Human Ecology Review 16:151-60.

Huebner, Bryce, Susan Dwyer, and Marc Hauser. 2009. "The Role of Emotion in Moral Psychology." Trends in Cognitive Sciences 13:1-6.

Kollmuss, Anja, and Julian Agyeman. 2002. "Mind the Gap: Why Do People Act Environmentally and What Are the Barriers to Pro-Environmental Behavior?" Environmental Education Research 8:239-60.

Kopnina, Helen. 2012. "The Lorax Complex: Deep Ecology, Ecocentrism and Exclusion." Journal of Integrative Environmental Sciences 9:235-54.

Korpela, Kalevi M., Terry Hartig, Florian G. Kaiser, and Urs Fuhrer. 2001. "Restorative Experience and Self-Regulation in Favorite Places." Environment and Behavior 33:572-89.

Kovan, Jessica T., and John M. Dirkx. 2003. "'Being Called Awake': The Role of Transformative Learning in the Lives of Environmental Activists." Adult Education Quarterly 53:99-118. 
Kretz, Lisa. 2012. "Climate Change: Bridging the Theory-Action Gap." Ethics \& the Environment $17: 9-27$.

Lange, Elizabeth A. 2004. "Transformative and Restorative Learning: A Vital Dialectic for Sustainable Societies." Adult Education Quarterly 54:121-39.

Le, Benjamin, and Christopher R. Agnew. 2003. "Commitment and Its Theorized Determinants: A Meta-analysis of the Investment Model." Personal Relationships 10:37-57.

Leopold, Aldo. (1949) 1989. A Sand County Almanac. Oxford: Oxford University Press.

Maiese, Michelle. 2013. "Moral Cognition, Affect, and Psychopathy." Philosophical Psychology 1-22, DOI: $10.1080 / 09515089.2013 .793916$.

Mairesse, Olivier, Cathy Macharis, Kenneth Lebeau, and Laurence Turcksin. 2012. "Understanding the Attitude-Action Gap: Functional Integration of Environmental Aspects in Car Purchase Intentions." Psicológica 33:547-74.

Maiteny, Paul T. 2002. "Mind in the Gap: Summary of Research Exploring 'Inner' Influences on Pro-Sustainability Learning and Behavior.” Environmental Education Research 8:299-306.

Mayer, F. Stephan, and Cynthia McPherson Frantz. 2004. "The Connectedness to Nature Scale: A Measure of Individuals' Feeling in Community with Nature." Journal of Environmental Psychology 24:503-15.

McCuen, Richard H., and Gaurav Shah. 2007. "Implications to Ethics Education of Recent Neuroscience Research on Emotions." Journal of Leadership Studies 1:44-56.

McKenzie-Mohr, Doug. 2000. "Promoting Sustainable Behavior: An Introduction to Community-Based Social Marketing." Journal of Social Issues 56:543-54.

Midden, Cees J. H., Florian G. Kaiser, and L. Teddy McCalley. 2007. "Technology's Four Roles in Understanding Individuals' Conservation of Natural Resources." Journal of Social Issues 63:155-74.

Müller, Markus M., Elisabeth Kals, and Ramune Pansa. 2009. "Adolescents' Emotional Affinity toward Nature: A Cross-Societal Study." The Journal of Developmental Processes 4:59-69.

Nisbet, Elizabeth K., John M. Zelenski, and Steven A. Murphy. 2011. "Happiness is in our Nature: Exploring Nature Relatedness as a Contributor to Subjective Well-Being." Journal of Happiness Studies 12:303-22.

Owens, Susan, and Louise Driffill. 2008. "How to Change Attitudes and Behaviors in the Context of Energy." Energy Policy 36:4412-18.

Palmer, Joy A., Jennifer Suggate, Barbara Bajd, Paul Hart, Roger K.P. Ho, J.K.W. OfwonoOrecho, Marjorie Peries, Ian Robottom, Elissavet Tsaliki, and Christie Van Staden. 1998. "An Overview of Significant Influences and Formative Experiences on the Development of Adults' Environmental Awareness in Nine Countries." Environmental Education Research 4:445-64.

Palmer, Joy A., Jennifer Suggate, Ian Robottom, and Paul Hart. 1999. "Significant Life Experiences and Formative Influences on the Development of Adults'Environmental Awareness in the UK, Australia and Canada." Environmental Education Research 5:181-200.

Ritter, Eva, and Dainis Dauksta. 2013. "Human-Forest Relationships: Ancient Values in Modern Perspectives." Environment, Development and Sustainability 15:645-62.

Savanick Guiney, Margaret, and Karen S. Oberhauser. 2009. "Conservation Volunteers' Connection to Nature." Ecopsychology 1:187-97.

Schultz, P. Wesley. 2002. "Inclusion with Nature: The Psychology of Human-Nature Relations." In Psychology of Sustainable Development, eds. Peter Schmuck and Wesley P. Schultz, 61-78. Dordrecht: Kluwer.

Schultz, P. Wesley, Chris Shriver, Jennifer J. Tabanico, and Azar M. Khazian. 2004. "Implicit Connections with Nature." Journal of Environmental Psychology 24:31-42.

Shove, Elizabeth. 2010. "Beyond the ABC: Climate Change Policy and Theories of Social Change." Environment and Planning A 42:1273-85.

Smith, P. Christopher. 1988. "The Ethical Dimensions of Gadamer's Hermeneutical Theory." Research in Phenomenology 18:75-91.

Sorrell, Steve, and Horace Herring. 2009. "Introduction." In Energy Efficiency and Sustainable Consumption. The Rebound Effect, eds. Horace Herring and Steve Sorrell, 1-20. Basingstoke: MacMillan.

Sponsel, Leslie E. 2011. "The Religion and Environment Interface: Spiritual Ecology in Ecological Anthropology." In Environmental Anthropology Today, eds. Helen Kopnina and Eleanor Shoreman-Ouimet, 37-55. Abingdon: Routledge. 


\section{Zygon}

Steg, Linda, and Charles Vlek. 2009. "Encouraging Pro-Environmental Behavior: An Integrative Review and Research Agenda." Journal of Environmental Psychology 29:309-17.

Tam, Kim-Pong. 2013. "Concepts and Measures Related to Connection to Nature: Similarities and Differences." Journal of Environmental Psychology 34:64-78.

Taylor, Bron. 2010. Dark Green Religion. Nature Spirituality and the Planetary Future. Berkeley: University of California Press.

Taylor, Edward W. 2007. "An Update of Transformative Learning Theory: A Critical Review of the Empirical Research (1999-2005)." International Journal of Lifelong Education 26:173-91.

Teper, Rimma, Michael Inzlicht, and Elizabeth Page-Gould. 2011. "Are We More Moral Than We Think? Exploring the Role of Affect in Moral Behavior and Moral Forecasting." Psychological Science 22:553-58.

Thøgersen, John. 2009. "The Motivational Roots of Norms for Environmentally Responsible Behavior." Basic and Applied Social Psychology 31:348-62.

Utsler, David. 2009. "Paul Ricoeur's Hermeneutics as a Model for Environmental Philosophy." Philosophy Today 53:173-78.

- 2014. "Environmental Hermeneutics and Environmental/Eco-Psychology: Explorations in Environmental Identity." In Interpreting Nature. The Emerging Field of Environmental Hermeneutics, eds. Forrest Clingerman, Brian Treanor, Martin Drenthen, and David Utsler, 123-40. New York: Fordham University Press.

van der Werff, Ellen, Linda Steg, and Kees Keizer. 2013. "The Value of Environmental Selfidentity: The Relationship between Biospheric Values, Environmental Self-identity and Environmental Preferences, Intentions and Behavior." Journal of Environmental Psychology 34:55-63.

van Tongeren, Paul J. M. 1994a. "Moral Philosophy as a Hermeneutics of Moral Experience." International Philosophical Quarterly 34:199-214.

_ 1994b. "The Relation of Narrativity and Hermeneutics to an Adequate Practical Ethic." Ethical Perspectives 1:57-70.

van Tongeren, Paul, and Paulien Snellen. 2014. "How Hermeneutics Might Save the Life of (Environmental) Ethics." In Interpreting Nature. The Emerging Field of Environmental Hermeneutics, eds. Forrest Clingerman, Brian Treanor, Martin Drenthen, and David Utsler, 297-312. New York: Fordham University Press.

Verplanken, Bas, and Rob W. Holland. 2002. "Motivated Decision Making: Effects of Activation and Self-Centrality of Values on Choices and Behavior." Journal of Personality and Social Psychology 82:434-47.

Walter, Pierre. 2013. "Dead Wolves, Dead Birds, and Dead Trees: Catalysts for Transformative Learning in the Making of Scientist-Environmentalists." Adult Education Quarterly 63:24-42.

Wells, Nancy M., and Kristi S. Lekies. 2006. "Nature and the Life Course: Pathways from Childhood Nature Experiences to Adult Environmentalism." Children, Youth and Environments $16: 1-24$.

Whitmarsh, Lorraine, and Saffron O’Neill. 2010. “Green Identity, Green Living? The Role of Pro-Environmental Self-identity in Determining Consistency across Diverse ProEnvironmental Behaviors." Journal of Environmental Psychology 30:305-14.

Williams, Richard N., and Edwin E. Gantt. 2012. "Felt Moral Obligation and the Moral Judgment-Moral Action Gap: Toward a Phenomenology of Moral Life." Journal of Moral Education 41:417-35. 
QUERIES

Journal: ZYGO

Paper: zygo12103

Dear Author

During the copy-editing of your paper, the following queries arose. Please respond to these by marking up your proofs with the necessary changes/additions. Please write your answers on the query sheet if there is insufficient space on the page proofs. Please write clearly and follow the conventions shown on the corrections sheet. If returning the proof by fax do not write too close to the paper's edge. Please remember that illegible mark-ups may delay publication.

\begin{tabular}{|l|l|l|}
\hline Query No. & Description & Author Response \\
\hline Q1 & $\begin{array}{l}\text { Author: Please check the keywords for } \\
\text { correctness. }\end{array}$ & \\
\hline Q2 & $\begin{array}{l}\text { Author: Please verify authors' affilia- } \\
\text { tions for correctness. }\end{array}$ & \\
\hline Q3 & $\begin{array}{l}\text { Author: Please provide the volume } \\
\text { number in reference Maiese (2013). }\end{array}$ & \\
\hline
\end{tabular}

